\title{
Genetic susceptibility to Parkinson's disease among South and North Indians: I. Role of polymorphisms in dopamine receptor and transporter genes and association of $D R D 4$ 120-bp duplication marker
}

\author{
Ramesh C. Juyal • Mitashree Das • Sohan Punia • \\ Madhuri Behari • Geetika Nainwal · Sumit Singh • \\ Pazhayannur V. Swaminath • Shyla T. Govindappa • \\ Sachi Jayaram • Uday B. Muthane • B. K. Thelma
}

Published online: 30 November 2007

(C) Springer-Verlag 2007

Erratum to: Neurogenetics (2006) 7:223-229

DOI 10.1007/s10048-006-0048-y

In the published original article, Table 3 , the authors noticed an error in the order of DRD3 SNPs which were used for haplotype construction. The 1st and 2nd SNPs were interchanged and the haplotypes were written in $3^{\prime}$ to $5^{\prime}$ ' direction.

The data for the other markers (DRD2 and DRD4) remain unchanged.

The correct DRD3 data are given here:

Table 3

\begin{tabular}{|c|c|c|c|c|c|c|}
\hline \multirow[t]{2}{*}{ Gene } & \multirow[t]{2}{*}{ Category } & \multirow[t]{2}{*}{ Haplotypes } & \multicolumn{2}{|c|}{ No. of chromosomes } & \multirow[t]{2}{*}{$\chi^{2}(p$ value $)$} & \multirow[t]{2}{*}{$\mathrm{OR}(95 \% \mathrm{CI})$} \\
\hline & & & Cases & Controls & & \\
\hline \multirow[t]{4}{*}{$D R D 3$} & \multirow[t]{4}{*}{ North India } & G-G-T-G & 10 & 2 & $5.47(0.02)$ & $5.21(1.12-23.45)$ \\
\hline & & G-A-T-G & 10 & 3 & $3.88(0.05)$ & $3.41(0.93-12.44)$ \\
\hline & & G-A-C-A & 22 & 5 & $11.12(0.0008)^{\mathrm{a}}$ & $4.56(1.71-12.13)$ \\
\hline & & G-A-C-G & 189 & 230 & $5.11(0.02)$ & $0.76(0.61-0.96)$ \\
\hline
\end{tabular}

DRD2 (5'-3')-141 ins/del C-Taq1b-Taq1d-Sau96I-HinCII-Taq1A, DRD3 (5'-3') Taq1-Ban1-Apo1-Msc1, DRD4 (5'-3') 120 bp dup-Fsp1-48 bp VNTR ${ }^{\mathrm{a}}$ Significant after Bonferroni correction $(\alpha=0.002$ for South India and 0.001 for North India)

The online version of the original article can be found at http://dx.doi. org/10.1007/s10048-006-0048-y of the article with published errors

\section{R. C. Juyal $(\bowtie) \cdot$ M. Das $\cdot$ G. Nainwal}

National Institute of Immunology, Aruna Asaf Ali Marg,

New Delhi 110067, India

e-mail: ramesh@nii.res.in

S. Punia $\cdot$ B. K. Thelma

Department of Genetics, University of Delhi South Campus,

New Delhi, India
M. Behari $\cdot$ S. Singh

Department of Neurology, All India Institute of Medical Sciences, New Delhi, India

P. V. Swaminath $\cdot$ S. T. Govindappa $\cdot$ S. Jayaram $\cdot$ U. B. Muthane Department of Neurology,

National Institute of Mental Health and Neurosciences,

Bangalore, India 